\title{
The Security and Human Rights Nexus in North Korea: Is Self-Organizing Dynamics Feasible?
}

\author{
Ki-Joon Hong
}

\begin{abstract}
The primary objective of this article is to examine the possibility of path emergence by institutionalizing the security and human rights nexus in North Korea. The underlying assumption of this study is that institutionalization of the security and human rights nexus in a repressive state sets in motion self-organizing dynamics which often shift the institutional path of the country from path dependence to path emergence, culminating in drastic socio-political transformation. Path emergence unfolds through the sequential phases of an influx of information, activation of frame resonance, strategic coordination in a network, a boomerang effect and finally a threshold effect. This theoretical framework is applied to the case of North Korea. This article argues that self-organizing dynamics may occur in North Korea if the security and human rights nexus in Korea were to be institutionalized within a single institutional framework.
\end{abstract}

Key Words: path dependence, path emergence, frame resonance, self-organization, human rights norms, transnational network, CSCE, Helsinki Final Act, Six-Party Talks.

\section{INTRODUCTION}

Over the past decade, North Korea's nuclear program and human rights violations have existed as a threat to international peace and security and have been the gravest concern of the international community. North Korea has not

* Ki-Joon Hong (kjhong@khu.ac.kr) is Professor at the Graduate Institute of Peace Studies (GIP), Kyung Hee University, Seoul, Korea. He studied at the University of Leuven in Belgium for his MA and Ph.D from 1990 to 1996. His latest publications include "Institutional Multilateralism in Northeast Asia: A Path Emergence Theory Perspective," Asian Studies Review, Vol. 11, No. 1, 2015, "Dynamics of Network Resonance: The Case of the Transnational Helsinki Network, " Europe-Asia Studies, Vol. 71, No. 1, 2019. 
yet halted its provocative actions and has instead continued testing nuclear weapons and ballistic missiles despite a series of international sanctions. In tandem with the nuclear crisis, the precarious humanitarian situation in the country has been exacerbated to the point of being a crime against humanity. This is in major part due to North Korea's intransigent position on human rights and its failure to commit to international human rights norms. These problems have raised a dilemma-type question as to how to deal with the threat from North Korea. With regard to this, two lines of thought are in competition at this moment. One holds that security issues should be separated from human rights concerns. Its underlying rational is that raising human rights problems in North Korea can be seen as a provocation and may scuttle efforts to resolve North Korea's nuclear problems through negotiations. Meanwhile, the other emphasizes that security issues should be linked to human rights concerns under any circumstance. Its proponents take the position that human rights are universal and inherent to all human beings, so the surest way to change North Korea is to defend the human rights of the North Korean population. Despite the rationale of these two approaches, there exists no consensus among analysts and policy makers.

Recently, as international sanctions against North Korea have tightened and consequently its human rights conditions have deteriorated, the voice of "human rights first" seems to have gained more support within the international societies. On December 22, 2017, the UN Security Council adopted Resolution 2397 unanimously in response to the ballistic missile launch by North Korea in violation of previous resolutions. This resolution further tightened sanctions on the country, severely restricting fuel imports and other trade, as well as the ability of its citizens to work abroad. Moreover, the Council affirmed that additional tests of nuclear weapons or long-range ballistic missiles by the country would result in further restrictions on its imports of petroleum (UN Security Council, 2017). Nevertheless, North Korea has pledged to continue its provocations because it firmly believes that the possession of nuclear weapons is key to its survival. If North Korea will not abandon its nuclear weapons, no matter what economic and political benefits it might receive in return, what would be a more integrated approach to dealing with North Korea?

With regard to this question, the security and human rights nexus in the Conference on Security and Cooperation in Europe(CSCE) exists as a reference for North Korea. Back in 1975, the 35 countries including the United States and Canada adopted the Helsinki Final Act, the final document resulting from three years of negotiations at CSCE. The Helsinki Final Act, included, among others, Principle 7, "Respect for Human Rights and Fundamental Freedoms, including the Freedom of Thought, Conscience, Religion or Belief" in Basket I and 
humanitarian provisions relating to freer movement of people and ideas in Basket III. Basket I made it possible for human rights activists in Eastern Europe and the Soviet Union to raise human-rights-related issues legitimately without conflicting with the principle of non-intervention in internal affairs. Meanwhile, Basket III opened the possibility for more normal relations between the East and the West by increasing contacts, interactions, travel and exchange of ideas. By incorporating human rights as a key security agenda in European politics normatively, the Helsinki Final Act spurred the development of the transnational Helsinki network across Europe, the Soviet Union and the United States. Helsinki activism triggered by the Helsinki Final Act significantly contributed to the demise of the communist regimes in Eastern Europe in 1989. This consequence was unforeseen at the time of signing the Helsinki Final Act. In this sense, the demise of the communist regimes at that time can be seen as an "unintended consequence" of the Helsinki Final Act (Thomas 2001).

The Helsinki effect has been referred to directly or indirectly in the process of legislation to link security and human rights in North Korea. For example, the North Korean Human Rights Acts were enacted in the US Congress in 2004 and in the Korean National Assembly in 2016 respectively. Moreover, the UN General Assembly voted to table the issue of North Korean human rights before the UN Security Council for its referral to the International Criminal Court in accordance with the UN Commission of Inquiry (COI) report in 2014. Nevertheless, there is presently insufficient evidence to argue that the legal approaches have significantly improved the North Korean human rights conditions and the ongoing nuclear standoff with the international community. Given this observation, I raise the following question: "Is the Helsinki model still valid for North Korea?" This article addresses this question from the theoretical perspective of "path emergence" (Hong 2013). The central argument of this perspective is that institutionalization of the security and human rights nexus in a repressive state sets in motion self- organizing dynamics which often shifts the institutional path of a country from path dependence to path emergence, culminating in drastic socio-political transformation in the country.

This article is organized into four sections. The first section elaborates the theoretical framework of the institutional transition from path dependence to path emergence through self-organizing dynamics of norm-based frame resonance. The second section examines the issues of the security and human rights nexus in North Korea. The third section explores the possibility of a selforganizing dynamics in North Korea in the future. The concluding section summarizes the research findings from the study. 


\section{A THEORETICAL FRAMEWORK}

In social science, institutions generally refer to arrangements involving a large number of people whose behavior is guided by norms and roles (Jary and Jary 2000). Institutional factors play a fundamental role in influencing the degree of power that one set of actors has over policy outcomes as well as influencing each actor's definition of his own interests by establishing his institutional responsibilities and relationships to other actors (Hall 1984). Institutions have been studied by social scientists from many different angles including rational choice institutionalism, historical institutionalism, sociological institutionalism and discursive institutionalism. Among these, historical institutionalists have developed the logic of path dependence in order to explain institutional self-reinforcing dynamics (Thelen 1999; Mahoney 2000; Pierson 2000 and 2004; Page 2006; Schreyoegg and Sydow 2011). According to Mahoney (2000), path dependence is self-reinforcing sequences in which initial steps in a particular direction induce further movement in the same direction, such that over time it becomes difficult or impossible to reverse direction. An institutional path is taken contingently at a critical juncture of history in which prior events or initial conditions trigger a move toward a particular path. Once a path is taken and locked-in, then positive feedback mechanisms reinforce the movement along the path. Positive feedback mechanisms act to reinforce an institution: when the benefit of its maintenance is larger than the cost; when it serves a function of an overall system; when it is supported by an elite group of actors; and when it is seen legitimate. The path changes or deviates when new events dislodge the long-lasting equilibrium with a new critical juncture.

Shifts in the path often culminate in unintended consequences that have not been anticipated by initial designers. The unintended path of institutional reinforcement is characterized by "emergent properties" transcending the properties of their constituent parts (Kauffman 1993). In this sense, the unintended path of institutional reinforcement may be called "path emergence" in contrast with "path dependence." The unintended path may arise from many different factors including cognitive biases, inappropriateness in intentions, functional disruption, goal displacement, exploitation, classification, over-commitment, placation, resource depletion leading to undershooting, countervailing reaction, and erosion of control leading to drift from intended outcome etc. (Perry 62014 ). Given the complexity of issues involved, any attempt to identify a law of unintended consequences may not be feasible, and thus goes beyond the scope of research. Path emergence in this context is understood as self-organizing dynamics which culminate in consequences with emergent or unintended 
properties as a result of institutional reinforcement.

The agreement of an international norm often becomes a critical juncture from which a chain of events unfolds with its own self-organizing dynamics. Once an international norm in a particular issue area is agreed upon by state actors and taken as an institutional path, the norms gain autonomous power to change the behavior of related actors through socialization processes leading from commitment to compliance. Especially, with regard to human rights norms, Risse, Ropp and Sikkink advanced the "spiral model" of human rights change (Risse et al, 2013). Their central argument is that the logic of actors is often embedded in a more encompassing logic of appropriateness of norm-guided behavior as institutionalized within human rights norms. They explain the spiral model as taking place in five distinct phases: repression, denial, tactical concessions, prescriptive status and rule-consistent behavior. In addition, they suggest the mechanisms and sequences by which the various modes of social action interact to bring about human rights change as follows: coercive measures such as use of force and legal enforcement, changing incentives through sanctions and rewards, persuasion and discourse through naming and shaming, and capacity building through institution-building, education and training. The spiral model of human rights has been a popular theoretical framework to study transnational human rights advocacy in relation to repressive states. However, it does not explain how human rights norms culminate in emergent or unintended consequences of socio-political transformation in the country.

Thus, the concept of path emergence is more focused on the self-organizing dynamics of norm-based frame resonance in a network through the following series of phases. 1

(1) Influx of information: self-organization of a network requires the influx of information about a particular event marked by the agreement of an international norm as a target of attention. A perceptual target encourages actors to focus their attention on the same external target through perceptual intersubjectivity.

(2) Activation of frame resonance: actors tend to be jointly committed to engaging in a joint action as a single entity. A joint commitment creates directed obligations, thus decoupling future actions from possibly fluctuating motivations (Gilbert 2006). A joint commitment in turn leads

1 For more details on the Helsinki effects based on this theoretical framework, see Ki-Joon Hong, "Dynamics of Network Resonance: The Case of the Transnational Helsinki Network," Europe-Asia Studies 71(1), 2019, pp. 1-19. Note that this theoretical framework was recited from this article published by the author. 
actors to establish a cognitive frame of advocacy. Such frames generate frame resonance that involves both the frame's internal coherence and its fit with a broader socio-political culture (Snow and Benford 1988). Frame resonance activates more effectively when actors formulate political coalitions as a hub of a transnational advocacy network.

(3) Strategic coordination: frame resonance is amplified by the strategic coordination of transnational actors. Four strategies are available for coordinative policy options: information politics, or moving politically usable information quickly and credibly to where it will have the most impact; symbolic politics, or calling upon symbols that make sense of a situation or claim for an audience that is frequently far away; leverage politics, or calling upon powerful actors to affect a situation where weaker members of network are unlikely to have influence; and accountability politics, or obliging more powerful actors to act on vaguer policies or principles they formally endorsed. This strategic coordination serves to exert pressure in order to induce state-actors to comply with their commitment to norms (Keck and Sikkink 1998).

(4) Boomerang effect: domestic actors in a repressive state bypass their state and directly seek international allies to try to bring pressure on their states from outside. By this effect, state-actors gradually change their policies. The repressive state first refuses to recognize the validity of international human rights norms. However, the state gradually shifts its position through tactical concessions in order to reduce pressure from the international community. With the rapid mobilization and further empowerment of domestic advocacy groups, the state grants human rights norms prescriptive status and finally complies with international human rights by taking rule-consistent measures (Keck and Sikkink 1998; Risse et al, 2013).

(5) Threshold effect: the movement of actors in a sequence of actions eventually becomes irreversible. The early development of events becomes deeply embedded in a particular environment, altering the resources, incentive structures, and hence the behaviors of actors, and thereby changes the social significance or pattern of unfolding of events or processes later in the sequence (Pierson 2000). At a certain point of a phase transition, incremental or cumulative processes may lead to a rapid "state change" in a repressive state once some critical level has been reached (Goldstone 1991). In this case, a critical level of resonance among actors plays an autocatalytic role for a chain of causally-linked events that, once set in motion, occurs independently of the norms that initially triggered it. Event sequencing is most salient when actors are densely entangled in a web of 
networks. This sequence of events, while ultimately linked to a critical juncture period, may culminate in unexpected or unintended consequences that are far removed from the original critical juncture (Mahoney 2001). This dynamics often spread the change pressure to other states, triggering a wave of socio-political transformation at the international level.

This theoretical framework is devised to explain how the self-organizing dynamics of norm-based frame resonance culminates in socio-political transformation in a repressive state. It is noted, however, that the consequences of the self-organizing dynamics may not be predictable as ex-ante facto; rather, they can only be construed as ex-post facto. The consequences may be either gradual human rights compliance or an abrupt collapse of the state, depending on the intensity of frame resonance and the conditions of socio-political structures in the repressive state.

\section{THE SECURITY AND HUMAN RIGHTS NEXUS IN NORTH KOREA}

The security and human rights nexus in North Korea has been addressed at two different levels: domestic or bilateral level and international or multilateral level. The domestic or bilateral level was first addressed by the US when the North Korean Human Rights Act (HR 4011, or the Act) was enacted in the US Congress modeling the Helsinki effect in October 2004. This is espoused in section 206 of the Act: "It is the sense of Congress that the United States should explore the possibility of a regional human rights dialogue with North Korea that is modeled on the Helsinki process, engaging all countries in the region in a common commitment to respect human rights and fundamental freedom." The act does not include any political overtones of regime change or any mention of the ongoing negotiations over North Korea's nuclear program in the Six-Party Talks. Representative James Leach, one of the primary sponsors of the bill in the House of Representatives, stated in the same vein: "I would like to reaffirm that the motivations for the North Korean Human Rights Act were (and are) solely humanitarian, not geo-strategic. The law is not a pretext for a hidden strategy to provoke North Korean collapse or to seek collateral advantage in ongoing negotiations." (House Committee on International Relations 2005). Despite this statement, the bill must have been enacted with the expectation of an effect similar to Helsinki in North Korea by directly linking security and human rights in North Korea. In that sense, the Act would have been consistent with President 
George W. Bush's belief that "the best hope for peace in our world is the expansion of freedom in the world" (The White House 2005).

The US' move was made against the backdrop of the negotiation process in the Six-Party Talks at that time. In that the main agenda of the Six-Party Talks was the North Korean nuclear issue, the US seemingly attempted to deal with the North Korean human rights issue on a different track. Indeed, in the first round of the talks in Beijing in 2003, the US repeated its demand that North Korea first dismantle its nuclear development program prior to any negotiations, while noting that it would move to establish diplomatic relations with Pyeongyang only after a variety of other issues are satisfactorily addressed, including North Korea's human rights record, and activities related to drug trafficking, counterfeiting, and terrorism (Kwak 2004). It turned out later on that this stiffened stance did not favor substantive progress in the talks. Thus, in the context of North Korean threats to halt progress on security issues in the case that human rights were added to the agenda, the US did not address human rights issues any more in the following rounds of the talks. This strategic calculation resulted in the exclusion of any provisions about North Korean human rights abuses in the Joint Statement of September 19, 2005 and February 13, 2007, except for the Japanese abductee issue in a watered-down tone. Differing from the approach seen within the Six-Party Talks, section 101 of the Act clearly states that "the human rights of North Koreans should remain a key element in future negotiations between the United States, North Korea, and other concerned parties in Northeast Asia."

HR 4001 contains provisions relating to the promotion of human rights, including support for human rights and democracy programs operating outside of North Korea, increased radio broadcasting through Radio Free Asia, and humanitarian assistance to international organizations operating within North Korea. In addition, section 302 grants North Korean escapees political asylum in the United States for the first time, allocating funds to help them settle permanently in the United States. North Korea reacted negatively to the passage of the act, criticizing that the US administration has neither the intention to roll back its hostile policy towards the DPRK nor any willingness to coexist with the DPRK. Conversely, human rights organizations were generally supportive of the act. For example, the largest organizations, Amnesty International, Human Rights First, and Human Rights Watch, all expressed their support. South Korean reaction varied. The progressive ruling party expressed opposition to the legislation, saying that "the act may have dire consequences for peace on the Korean peninsula," and "is perceived as aiming to overthrow the Kim Jong-Il government" (Change 2004). Meanwhile, the conservative opposition party expressed cautious support for the act and even suggested that they might 
introduce similar legislation in the South Korean National Assembly in 2005 (Kim 2005). Among neighboring countries, Japan supported the Act and promulgated similar legislation in 2006 while China remained silent.

While HR 4011 has stood as separate legislation to promote North Korean human rights by being reauthorized every year, the North Korea Sanction and Policy Enhancement Act was passed in February 2016 to focus on trade sanctions due to continued North Korean missile and nuclear testing. The new law inextricably makes human rights improvement conditional to the lifting of US sanctions, permanently and effectively linking human rights to the security issue of North Korea (Goedde 2017). This linkage was further solidified by the US Department of the Treasury's Office of Foreign Assets Control (OFAC) designation of North Korean Leader Kim Jong Un, ten officials, and five entities for ties to North Korea's notorious abuses of human rights (US Department of Treasury's Office of Foreign Assets Control 2016). Although the Treasury designation was more symbolic than practical, it signaled that human rights had been firmly incorporated as a priority in political dealings with North Korea (Goedde 2017).

In South Korea, the North Korean Human Rights Act was enacted in March 2016 after a long contest in the National Assembly over ten years. During its formulation, North Korea policy was developed and modified through extensive negotiations between parties with diverse interests and perspectives. The progressive opposition party fundamentally opposed its enactment as it proposed to instead negotiate with and provide further aid to North Korea. The law represents a certain degree of bipartisan concession that North Korean human rights needs to be addressed in a more formal and unified manner by the South Korean government (Goedde 2017). The Act created a North Korean human rights advisory committee under the Ministry of Unification; a North Korean Human Rights Foundation to help research, strategize, and fund human rights improvement in North Korea; a Human Rights Archive tasked with collecting and recording information pertaining to human rights and humanitarian assistance, and the appointment of a North Korean Human Rights Ambassador-at-large by the Ministry of Foreign Affairs (ROK North Korean Human Rights Act 2016). North Korean authorities were evidently disturbed by the implementation of the Act, criticizing it as "absurd and futile, like trying to break a rock with an egg" (Moon 2016).

Meanwhile, at the international or multilateral level, the UN Human Rights Council established a Commission of Inquiry (COI) on human rights in North Korea in March 2013. As the members of the commission, Special Rapporteurs were mandated to "investigate the systematic, widespread and grave violations of human rights in the State, with a view to ensuring full accountability, in 
particular, for violations that may amount to crimes against humanity" (UN Human Rights Council 2014). However, North Korea publically stated that it would totally reject and disregard it. Accordingly, it did not respond to the commission's repeated requests for access to the country and to information on the human rights situation. Despite its lack of access to the country, the COI released a report based on first-hand testimony through public hearings in 2014. According to this report, "systematic, widespread and gross human rights violations have been and are being committed by the Democratic People's Republic of Korea. In many instances, the violations found entailed crimes against humanity based on State policies" (UN Human Rights Council 2014). On the basis of this conclusion, the COI recommended that "the Security Council should refer the situation in North Korea to the International Criminal Court for action on accordance with that court's jurisdiction" (UN Human Rights Council 2014). This means that the human rights discourse on North Korea shifted from investigation and monitoring of human rights violations to legal accountability. This represents a critical turning point in linking North Korean human rights to international peace and security as a de facto judicial or prosecutorial matter.

Facing increasing international human rights pressure, North Korea recently ratified the Optional Protocol to the Convention on the Rights of the Child in 2014, and the Convention on the Rights of the Persons with Disabilities (CRPD) in 2016. North Korea also took a number of positive steps to engage with UN human rights mechanisms: the visit of the disability rapporteur; the submission of reports on women's and children's rights to the UN treaty bodies; and the acceptance of more than 100 recommendations made to North Korea by UN member states at the Universal Periodic Review (UPR) (UN General Assembly 2017). However, North Korea's ratification of international treaty bodies and engagement with UN human rights mechanisms do not necessarily mean that it intends to improve its human rights conditions via domestic implementation. These are just tactical concessions, not supported by significant domestic transformation, to cope with the situation that North Korea has been sufficiently shamed by the international community.

As shown above, the international community has consistently raised concerns about North Korean human rights abuses by linking security and human rights directly or indirectly at the country and the UN level. The North Korean authorities, nonetheless, did not show any willingness or effort to improve the human rights conditions in North Korea. They have ignored or refused the international community's raising of human rights issues, contending instead that such actions by the international community amount to intervention in their domestic affairs and encroachment on their national sovereignty. In contrast to the CSCE, the 
security and human rights nexus applied to North Korea has not yet had any similar impact on North Korea. North Korean Human Right Acts are only superficially similar to the Helsinki Final Act in that they are a part of a process of linking human rights issues to international security concerns without possessing the necessary consent from the relevant state actors involved in the North Korean nuclear issue (Hwang and Kim 2006). Indeed, the Acts lack the legitimacy of the Helsinki Final Act, and thus are not likely to have similar effects of norm-based frame resonance on North Korea. International pressure through UN human rights mechanisms was not fruitful because there remains a huge gap in the concept of human rights between the international community and North Korea. North Korea as a unique socialist country is asserting Marxist human rights and "our style of human rights" based on Juche ideology. These are the opposite of the concept of universal human rights shared by the international community and are escalating the issue by applying a "double standard" to human rights. Thus, without significant changes in this situation, it looks pessimistic that North Korea has been led to take an emergent path beyond the problems of its nuclear program and human rights violations.

\section{PROSPECTS OF SELF-ORGANIZING DYNAMICS IN NORTH KOREA}

It has been speculated that a Helsinki-style approach to the ongoing North Korean nuclear standoff and human rights abuses may be applied to the Six-Party Talks. The Six-Party Talks were initiated as an ad hoc multilateral framework for dealing with the second round of the North Korean nuclear crisis in 2003. Since then, the talks have functionally expanded and been institutionally reinforced through five rounds of talks, with occasional fluctuations of ups and downs. There was hope that the successful completion of the talks would lead to the denuclearization of the Korean peninsula, a formal ending of the Korean War with a peace treaty, and the building of a Northeast Asian security mechanism (Hong 2012). Even though the talks have been stalled since November 2008, the Six-Party Talks have the potential to be equivalent of the CSCE in institutionalizing the security and human rights nexus in North Korea.

It seems that the resumption of the new Six-Party Talks requires at least two preconditions. The primary one is a bold approach with a new way of calculation as the North has claimed. This may be a tacit recognition of the North Korean nuclear status by the other parties, as the opening of the CSCE was possible by the West's recognition of the territorial status quo in Europe. Tacit recognition 
of North Korea's nuclear status does not necessarily mean an official and permanent one. On the contrary, it is a strategical and tentative recognition to induce North Korea to multilateral negotiations. It is considerable because the UN sanctions remain limited in their deterrent effects and the US' military options are unrealistic unless the concerned parties were to agree to them. The second condition is a thawing of tensions around the Korean peninsula, as the CSCE opened at the peak of détente in the early 1970s. It is noted that amid heightened tensions around the Korean peninsula, North Korea's leader Kim Jong Un unexpectedly announced Pyongyang's participation in the 2018 Winter Olympics in South Korea. The announcement was followed by South Korean government's agreement to participate in the first high-level talks with the North since December 2015. In preparation for the talks, the two countries restored the Seoul-Pyongyang hotline, which had been inactive for almost two years. Since then, a series of summits have been followed signaling a drastic change in inter-Korean relations and the security environment in Northeast Asia. However, the Korean peninsula peace process has halted again without any substantial results. With the advent of a new administration in the US recently, it is too early to predict at this moment how its policy toward North Korea will shape in the future. Nevertheless, it can be reasonably predicted that the new US administration is likely to attach more values on human rights in North Korea than before. This means that the security and human rights nexus will resurge as a US foreign policy under the Biden administration.

It is speculated that if the issue of denuclearization of the Korean peninsula is back on track between the US and North Korea, talks about the resumption of the Six-Party Talks might be stirred up among the concerned parties. Because the bilateral nuclear deals under the Trump administration were not fruitful, the new US administration may consider a multilateral approach resembling the Iran nuclear deal framework as an alternative option. In this case, North Korea would be expected to demand, as precondition, the recognition of its nuclear status, the lifting of UN sanctions, and the moderating of the US' hostile policy, and accordingly, the halting of ROK-US joint military exercises. For this reason, the way toward the resumption of the Six-Party Talks appears to be bumpy rather than rosy. However, it is not impossible to find an outlet if the US takes a bold approach to North Korea by taking the CSCE as a reference. Recall that the East accepted human rights as an agenda of the CSCE in return for the West's recognition of frontier inviolability. Once the Six-Party Talks are back on track, human rights issues might be raised in the talks as a bargaining mix of a package deal. For a successful package deal, the agenda of the new Six-Party Talks needs to be comprehensive like in the case of the CSCE, including an unprecedented scale 
of humanitarian and economic aid to North Korea as a tradeoff for freezing or dismantling its nuclear weapons.

Even if human rights were adopted as an agenda of the talks and set as agreed norms, it is naive to expect that the effect would immediately show in North Korea as in the Eastern European countries. This is because the self-organizing dynamics of norm-based frame resonance requires the influx of information about the norms into the country. Indeed, information flow is restricted in North Korea by means of border controls, electronic jamming and punishment for possession of audio-visual recordings. North Korean residents are not allowed to move freely through various systems such as food distribution and registration. Information about the outside world is controlled by government authorities in order to prevent elements of capitalism from infiltrating the society. Any gathering without permission from the authorities is regarded a reactionary group, and ordinary residents are not allowed to organize any form of voluntary association. However, currently, North Korean society is gradually undergoing a variety of changes. Among others, the increasing use of mobile phones has had enormous impact on the life of North Korean population. The use of mobile phones makes it possible for outside information to flow into the North Korean society. This new social change significantly contributes to the circulation of outside information, which enables North Korean people to change their views on freedom of expression, assembly and association. In the long run, we cannot rule out the possibility that the newly perceived human rights norms by the North Korean population will become a source of frame resonance by which they are jointly committed to engaging in joint actions.

As mentioned earlier, for frame resonance to activate effectively, human rights norms need to be internally coherent and fit with a broader socio-political culture in North Korea. Even though North Korea introduced the term "human rights" into its Constitution in 2009, it has prioritized cultural relativism over universalism, collective interests over individual interests, socio-economic rights over civil and political rights, and duties before rights (Weatherley and Song 2008). The concept of human rights has been used within the unique cultural, political and ideological context of North Korea. Given this fact, the question is how to localize human rights norms and intensify rights consciousness within the Korean society. One recommendation may be to disseminate information about the agreed human rights norms and the reality of North Korean population from the perspective of North Korean defectors. Information can brought into North Korean society through many different channels such as radio transmissions, leaflets, DVDs, and USB drives etc. By doing so, the North Korean population could realize that there is a huge discrepancy between what they are indoctrinated by the North Korean 
authorities and the international principle of human rights. Moreover, they could also become aware of the fact that nuclear weapons are threatening to their inherent human rights and are detrimental to national security. Indeed, the awareness of their "rights" is essential for the self-organizing dynamics of normbased frame resonance that can lead to socio-political transformation in North Korea.

Currently, diverse actors such as the UN agencies, national governments and non-governmental organizations (NGOs) are involved in North Korean human rights. However, they are not systematically networked as the transnational Helsinki network was. In the case of the Helsinki norms, human rights activists shared the similar view that the Helsinki norms could be an opportunity or a legitimatizing tool for pressuring the Soviet and Eastern bloc countries to honor their human rights commitments. This resulted in formulating a cognitive frame of advocacy from which joint actions were taken to establish Helsinki networks in the US and the USSR independently. In the West, the Commission on Security and Cooperation in Europe, a legislative-executive commission, was established in the US in 1975 with a goal of monitoring implementation of the act. Following the establishment of the Commission, a number of similar organizations emerged in Western countries. As the need for coordination among the groups increased, the International Helsinki Federation for Human Rights (IHF) was established as a formal umbrella organization in Vienna in 1982. The membership of this organization increased to 44 Helsinki committees throughout Europe, North America, and Central Asia. By building a transnational coalition, the IHF served as a hub for the transnational Helsinki network. Meanwhile, in the East, the Moscow Helsinki Group was established in 1976 in the USSR by a few prominent dissidents. The Moscow Helsinki Group helped unite different dissident movements and encouraged them to recognize the relevance of the Helsinki norms to their particular concerns, and to organize accordingly. As a result, over the following year, the number of similar groups mushroomed in the USSR and Eastern European countries. The transnational Helsinki network intensified frame resonance based on Helsinki norms throughout the CSCE states (See Hong 2019).

The lack of a systemic network of various actors with regard to North Korean human rights is mainly because there are no such human rights norms agreed upon by North Korea as equivalent to the Helsinki Final Act. While North Korean Human Rights Acts are operating in the US and South Korea, there is no close coordination between their operations. Moreover, even though North Korea is engaged in a few international human rights treaties, the binding effect of those treaties still remains limited. Thus, in the absence of a transnational network and 
domestic human rights advocacy groups in North Korea, it is difficult to expect a boomerang effect to occur in North Korea through strategic coordination in information politics, symbolic politics, leverage politics, and accountability politics. To remedy these shortcomings, the existing norms and mechanisms of North Korean human rights need to be more systematically networked through the forming of an institutional platform within the UN system as a hub of the transnational network.

Increasing the involvement of North Korean human rights actors through a sequence of joint actions at the domestic and international level would be expected to eventually change the perception of human rights in North Korean society, the incentive structures between security and human rights, and ultimately the behaviors of North Korean population. At a certain point in the institutionalization process of the security and human rights nexus in North Korea, a critical juncture, incremental or cumulative frame resonance may lead to a rapid "state change" in North Korea. In this case, a critical level of resonance between the North Korean population and North Korean human rights activities may trigger a chain of causally-linked events that, once set in motion, would continue regardless of the human rights norms in North Korea. This self-organizing dynamics of normbased frame resonance may culminate in a drastic socio-political transformation in North Korea. The consequences may be either gradual human rights compliance or an abrupt collapse of North Korea. That outcome would depend on how the North Korean regime manages the security and human rights nexus and adapts to the changing environment in the future. Currently, North Korea stands at the crossroad of path dependence and path emergence.

\section{CONCLUSION}

This article was motivated by the question why the security and human rights nexus in North Korea has not been fruitful, differing from the case of the CSCE, which culminated in the demise of communist ruling in the Eastern European countries in 1989. In order to address this question, this article has presented the concept of path emergence as a theoretical framework. The concept of path emergence is based on the assumption that institutionalization of the security and human rights nexus in a repressive country may set in motion self-organizing dynamics of norm-based frame resonance by which the country changes its path-dependent policies, culminating in path-emergent consequences. It has been argued that the self-organizing dynamics of norm-based frame resonance unfold 
in a chain of events: an influx of information, activation of frame resonance, strategic coordination, a boomerang effect, and lastly a threshold effect.

In the case of the CSCE, the security and human rights nexus in the Helsinki Final Act was successfully institutionalized thanks to the favorable conditions that existed at that time. While the idea of the CSCE was originally initiated by the East, the West proactively responded to the initiative at the changing international climate of détente. The East's request for recognition of the territorial status quo was reciprocated by its acceptance of West's request for human rights as an agenda of the CSCE. Through adroit mediation by neutral and non-allied countries, human rights and freer movement were incorporated into the Helsinki Final Act as essential norms for international security relations in Europe. The signing of the Helsinki Final Act made it possible for activists to raise human rights-related issues legitimately without infringing upon the principle of non-intervention in international affairs. Institutionalization of the security and human rights nexus in the CSCE set in motion the self-organizing dynamics of norm-based frame resonance, which culminated in the unintended consequence of the drastic socio-political transformation of Eastern European countries in 1989.

The Helsinki model may not be directly applied to North Korea at this moment mainly because of the different geo-political conditions of Northeast Asia and the learning effect of the Helsinki Final Act. China and North Korea are particularly sensitive to the human rights issue, still regarding it as a matter of internal affairs. For North Korea, raising human rights issues is seen as an attack upon its national sovereignty and thereby a threat to its national security. However, with the increasing level of UN sanctions against North Korea's ambition to possess nuclear weapons and the international community's pressure on North Korean human rights abuses, North Korea may seek an outlet for its regime survival by means of dialogue.

It is currently reported that the North Korean economy seriously suffers under sanctions and COVID19. Despite robust diplomatic engagements with South Korea and the United States over the past two years, the failure to secure any level of sanctions relief led Kim Jong Un to set forth a new approach to economic policy and management. Kim Jong Un's address to the Central Committee at the end of 2019, after a prolonged stalemate of US-DPRK diplomatic talks and a total breakdown in inter-Korean talks, focused on revising the fundamentals of the economy and economic management (Babson 2021). In this situation, if the thawing of tensions around the Korean peninsula is sustained, and the new US administration takes a bold approach to North Korea, it is not unlikely that North Korea may return to negotiations for nuclear deals. Of course, meeting this new 
development would require a drastic turnabout of policies from the side of the US, China, and North and South Korea in particular. It is highly probable that the concerned parties may consider a multilateral approach rather than a bilateral approach in dealing with North Korea's nuclear issue.

In the course of seeking a breakthrough, the stalled Six-Party Talks may be revived as an institutional option for dealing with the North Korean nuclear and human rights issues. Unlike the previous rounds of the talks, if new talks were to succeed in institutionalizing the security and human rights nexus in the single institutional framework, it can be said that there would be room for the selforganizing dynamics of norm-based frame resonance in North Korea. The key to this is the influx of information about new norms into North Korean society through strategic coordination in the domestic and transnational human rights advocacy network. As North Korean society gradually changes, North Korean versions of the boomerang and threshold effects may not be ruled out at its own critical juncture, regardless of whether it is intended or unintended. In this sense, it can be concluded that a self-organizing dynamics may occur in North Korea if the security and human rights nexus was to be institutionalized in the future.

\section{REFERENCES}

\section{PRIMARY SOURCES}

Document CSCE/HC/18, 15 January 1973.

Document CSCE/HC/22, 17 January 1973.

Document CSCE/HC/26, 25 January 1973.

Document CSCE/WT/VR.13, 1973.

ROK North Korean Human Rights Act 2016, Law No. 14070.

UN Human Rights Council. 2014. "Report of the commission of inquiry on human rights in the Democratic People's Republic of Korea." Distr.: General.

UN General Assembly. 2014. Report of the Working Group on the Universal Periodic Review: DPRK, A/HRC/27/10/Add.1.

UN Security Council. 2017. S/RES/2397.

US Department of Treasury's Office of Foreign Assets Control (OFAC)'s "Report on Serious Human Rights Abuses or Censorship in North Korea," July 6, 2016. Assessed at https://beyondparallel.csis.org/human-rights-sanctionsfor-north-korea/ (February 2, 2020) 


\section{SECONDARY SOURCES}

Babson, Bradley O. 2020. "The North Korean Economy Under Sanctions and COVID-19,” The Diplomat. Assessed at https://beyondparallel.csis.org/ human-rights-sanctions-for-north-korea/ (January 5, 2021).

Chang, Se-Moon. 2004. “The North Korean Human Rights Act.” Seoul Times (3 December).

Gilbert, Margaret, $A$ Theory of Political Obligation: Membership, Commitment and the Bonds of Society. Oxford: Clarendon Press.

Goedde, Patricia. 2017. "Human Rights Diffusion in North Korea: The Impact of Transnational Legal Mobilization." Asian Journal of Law and Society, 1-29, at https://www.cambridge.org/core/journals/asian-journal-of-lawand-society/article/human-rights-diffusion-in-north-korea-the-impactof-transnational-legal-mobilization/A888AD94D6BC55FA8734AD7271D A89BE (May 20, 2020).

Goldstone, Jack A. 1991. Revolution and Rebellion in the Early Modern World. Berkeley: University of California Press.

Hall, Peter A. 1984. Governing the Economy: The Politics of State Intervention in Britain and France. New York: Oxford University Press.

Hong, Ki-Joon. 2012. "The Six-Party Talks in the Post-Kim Jong-il Era: An Emergent Path toward a Northeast Asian Security Mechanism.” North Korean Review 8(2), 111-528.

Hong, Ki-Joon. 2013. "The Unintended Consequences of the Helsinki Final Act: A Path Emergence Theory Perspective." International Political Science Review 34(3), 310-325.

Hong, Ki-Joon. 2019. "Dynamics of Network Resonance: The Case of the Transnational Helsinki Network." Europe-Asia Studies 71(1), 1-19.

House Committee on International Relations, Subcommittee on Asia and the Pacific. 2005. The North Korean Human Rights Act of 2004: Issues and Implementations, 109th Cong., 1st sess..

Hwang, Jaeho and Jasper Kim. 2006. "Defining the Limits of the North Korean Human Rights Act: A Security and Legal Perspective.” East Asia 23(4), 45-60.

Jary, David and Julia Jary. 2000. Collins Dictionary of Sociology. Glasgow: Harper Collins.

Kauffman, Stuart A. 1993. The Origins of Order: Self-Organization and Selection in Evolution. Oxford: Oxford University Press.

Keck, Margaret E. and Kathryn Sikkink. 1998. "Transnational advocacy networks in international and regional politics." International Social Science Journal51(159), 89-101. 
Kim, So Young. 2005. “Opposition Seeks NK Rights Act," Hangug Ilbo (26 January). Korey, William. 1993. The Promises We Keep: Human Rights, the Helsinki Process, and American Foreign Policy. New York: St. Martin's Press.

Kwak, Tae-Hwan. 2004. "The Six-Party Nuclear Talks: An Evaluation and Policy Recommendation." Pacific Focus XIX(2), 1-55.

Mahoney, James. 2000. "Path Dependence in Historical Sociology." Theory and Society 29(4), 507-548.

Mahoney, James. 2001. The Legacies of Liberalism: Path Dependence and Political Regimes in Central America. Baltimore: Johns Hopkins University Press.

Maresca, John J. 1985. To Helsinki: The Conference on Security and Cooperation in Europe, 1973-1975. Durham and London: Duke University Press.

Moon, Sun Bo. 2016. "The North Korean Human Rights Act: A first step towards 'unconventional normalization." Daily NK (16 September).

Page, Scott E. 2006. "Path Dependence.” Quarterly Journal of Political Science $1(1), 87-115$.

Perry, 6. 2014. "Explaining Unintended and Unexpected Consequences of Policy Decisions: Comparing Three British Governments, 1959-74.” Public Administration 92(3), 673-691.

Pierson, Paul. 2000. "Increasing Returns, Path Dependence, and the Study of Politics.” American Political Science Review 94(2), 251-267.

Pierson, Paul. 2004. Politics in Time: History, Institutions, and Social Analysis. Princeton: Princeton University Press.

Remington, Robin Alison. 1971. The Warsaw Pact: Case Studies in Communist Conflict Resolution. London: The MIT Press.

Risse, Thomas, Stephen C. Ropp, and Kathryn Sikkink. 2013. The Persistent Power of Human Rights: From Commitment to Compliance. Cambridge: Cambridge University Press.

Schreyoegg, George and Jörg Sydow. 2011. "Organizational Path Dependence: A Process View.” Organization Studies 32(3), 321-335.

Sizoo, Jan and Rudolf Th. Jurrjens. 1984. CSCE Decision Making: the Madrid Experience. The Hague: Martinus Nijhoff Publishers.

Snow, David and Robert D. Benford. 1988. "Ideology, Frame Resonance and Participant Mobilization." International Social Movement Research 1(1), 197-317.

Snyder, Sarah B. 2011. Human Rights Activism and the End of the Cold War: A Transnational History of the Helsinki Network. Cambridge: Cambridge University Press.

The White House. 2005. "President Bush Sworn-In for Second Term.” Assessed 
at http://www.whitehouse.gov/inaugural (April 30, 2020).

Thelen, Kathleen. 1999. "Historical Institutionalism in Comparative Politics." Annual Review of Political Science 2, 279-297.

Thomas, Daniel C. 2001. The Helsinki Effect: International Norms, Human Rights, and the Demise of Communism. Princeton and Oxford: Princeton UN General Assembly. 2017. Report of the Special Rapporteur on the situation of human rights in the DPRK, A/72/394, para. 18. University Press. Weatherley, Robert and Jiyoung Song. 2008. "The Evolution of Human Rights Thinking in North Korea." Journal of Communist Studies and Transition Politics 24(2), 272-296.

[Received Nov 18, 2020; Revised Feb 21, 2021; Accepted Mar 2, 2021] 